\title{
Artificial Intelligence for Future Lunar Societies: A Critical Analysis of the Liability Problem
}

\author{
loana Bratu
}

\author{
Researcher \& Lecturer, Amsterdam Law \& Technology Institute / ALTI \\ Law Faculty, Vrije Universiteit Amsterdam, the Netherlands
}

\begin{abstract}
Artificial intelligence $(\mathrm{Al})$ is transforming the space industry by offering unprecedented possibilities for space related activities. Al applications in space include from analysing large amounts of space data, enabling deep-space missions, mitigating the effects of climate change, combating space pollution, to assisting astronaut crews during their daily operations. In the context of building future human societies on the Moon, Al systems will play a double role: an ex-ante preparation role and a societal consolidative role. Al systems used in the ex-ante preparation phase include various applications used for exploration investigations and they will be decisive for the scientifical understanding of the future Lunar habitat. Once the habitats will be settled, Al systems will contribute for consolidation, playing an assistive role, among others. Al systems will be able to offer support in daily activities, including offering mental health assistance. Similar systems have already been successfully deployed on the International Space Station, for crew assistance.
\end{abstract}

The introduction of $\mathrm{Al}$ systems as part of future Lunar habitats does not come without corresponding risks, especially from a legal perspective. Several legal challenges may appear in the context of a high reliance on these systems, such as: who will be liable in case an Al system will be involved in accidents causing economic losses or loss of human lives? What type of legal framework will be required to mitigate such risks? Will the existing body of laws representing international space law remain sufficient for addressing these challenges?

In such context, the purpose of this paper is to critically analyse the above-mentioned legal risks and to propose corresponding mitigating actions for ensuring long-standing future Lunar societies.

\section{Key words: liability, artificial intelligence, Moon Agreement, Liability Convention}

\section{Introduction}

One of the major milestones in human space exploration is represented by NASA's commitment to landing American astronauts on the Moon, by 2024. Given such ambitions, the concept of a permanent human settlement, a future Lunar society, no longer seems like an utopian scenario. In order to accomplish such complex objectives, future missions will use innovative new technologies and systems to explore the Moon more than ever before. ${ }^{1}$

A variety of systems enabled by artificial intelligence (Al) have already been deployed in space and similar systems will contribute in achieving Moon exploration goals as well as in developing future Lunar societies. For example, autonomous Lunar rovers will be especially designed for transporting astronauts on the Lunar surface and for assisting them during their exploration missions. The Lunar rovers use Al for navigating on the Moon, similarly with the rovers launched in the context of Mars exploration. Al capabilities will also be used for "vehicle system management", meaning that they will transform the astronaut's spacecraft into a robot for performing various tasks. Because the Moon has an uneven surface, this might have a significant impact towards the future locations of Lunar habitats. In this respect, several types of Al systems are currently being used for identifying and mapping the location of Lunar craters and for creating Lunar crater databases.

\footnotetext{
1 See Jeremy D. Frank, Artificial Intelligence: Powering Human Exploration of the Moon and Mars, ARXIV:1910.03014 [CS] 1 (Oct. 2019).
} 
Assistive technologies enabling consolidation of Lunar societies are also driven by Al capabilities and proved useful in previous space related activities, for example, the deployment of Al assistants on the board of the International Space Station.

In the light of these technological developments, international space law is at a crossroad, potentially requiring new interpretations of various legal notions or initiating amendments of existing treaties.

\section{Artificial Intelligence: Definition and Applications from Earth to Space}

Automated decision-making systems, commonly referred to as "Al systems", have been introduced in a variety of sectors, from health, agriculture to legal services, granting loans and retail. ${ }^{2}$ This phenomenon led to a necessary evaluation of risks and potential benefits of this emerging technology. ${ }^{3}$ International and regional initiatives proposed various definitions for the concept.

For the purpose of this paper Al systems are defined in accordance with the provisions of the European Proposal for an Al Act ${ }^{4}$. Article 3 of the European Proposal for an Al Act provides a comprehensive definition of Al systems, as follows:

"Al system means software that is developed with one or more of the techniques and approaches listed in Annex I and can, for a given set of human-defined objectives, generate outputs such as content, predictions, recommendations, or decisions influencing the environments they interact with." The techniques included in Annex 1 are the following:

"(a) Machine learning approaches, including supervised, unsupervised and reinforcement learning, using a wide variety of methods including deep learning;

(b) Logic- and knowledge-based approaches, including knowledge representation, inductive (logic) programming, knowledge bases, inference and deductive engines, (symbolic) reasoning and expert systems;

(c) Statistical approaches, Bayesian estimation, search and optimization methods.

As such, in the opinion of the European legislator, the concept includes from basic systems, such as symbolic expert systems, to more advanced systems, reaching high automation levels and operating based on sophisticated learning approaches, such as machine learning, a process inspired by the neural networks of the human brain. ${ }^{5}$

A key element in differentiating between various $\mathrm{Al}$ systems is the degree of human control deployed in the decision-making process. Automated decision-making implies a delegation process from a user to an entity, by means of a software or service. The system then uses automatically executed decisionmaking models with the purpose of performing an action on behalf of a user. ${ }^{6}$ In case of advanced systems, the human control decreases up to the point where an operator of such an Al system may claim that an activity performed by the system was outside of his or her control because it was executed by an autonomous operation of the Al system. ${ }^{7}$

\footnotetext{
${ }^{2}$ What is Artificial Intelligence and How is It Used? / News / European Parliament, https://www.europarl.europa.eu/news/en/headlines/society/20200827STO85804/what-is-artificialintelligence-and-how-is-it-used (last visited Feb. 14, 2021).

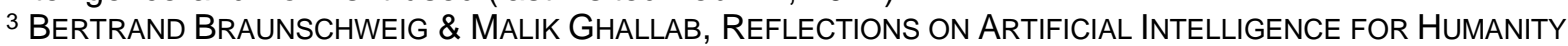
(Springer 2021).

${ }^{4}$ European Commission, Proposal for a Regulation of the European Parliament and of the Council laying down harmonised rules on artificial intelligence) and amending certain Union legislative acts (COM(2021) 206 final)

5 loana Bratu et al., Autonomous Space Objects and International Space Law: Navigating the Liability Gap, 18 INDONESIAN JOURNAL OF INTERNATIONAL LAW 423 (Mar. 2021).

${ }^{6}$ European Parliament and Council, Draft Report with Recommendations to the Commission on a Civil Liability Regime for Artificial Intelligence, No. P9_TA(2020)0276 (Apr. 2020).

7 Id.
} 


\subsection{Artificial Intelligence and Space Related Activities}

In space related activities, autonomy is currently treated as top priority. Fully autonomous systems will function without human intervention: moving, seeing, thinking, learning, and acting on their own. ${ }^{8} \mathrm{Al}$ will give the autonomous system its decision-making capabilities, drawing on massive libraries and efficient analysis made possible by innovations in data science. ${ }^{9}$ Some future space exploration missions will have limited communication with Earth, requiring the systems to be able to assess their own environment and make decisions independently. ${ }^{10}$ Missions that cannot receive commands from Earth quickly and reliably will need the autonomous capability to explore with reduced or no human intervention. ${ }^{11}$

NASA has been developing a series of projects employing Al techniques over the last decade. An example is the NASA Autonomous Systems and Operations project, which made use of Al techniques in three distinct ways for enabling autonomous mission operations capabilities: (i) crew autonomy, (ii) vehicles system management and (iii) autonomous robots. ${ }^{12}$ Crew autonomy assists astronauts in the performance of their missions while the vehicle system management uses Al techniques to transform the astronaut's spacecraft into a robot, allowing it to operate when astronauts are not present. Autonomous robots operating based on Al technologies are also used for assisting astronauts, as crew assistants or proxies when the crew are not present.

Al is also actively used in satellite operations, for supporting the operations of large satellite constellations such as positioning, communication and end-of-life management. ${ }^{13}$ In addition, it is increasingly becoming common to find various types of Al techniques analysing "space Big Data", meaning the huge amount of data gathered from each space mission. ${ }^{14}$

In addition, Al techniques are deployed for space sustainability purposes, with a number or projects leveraging Al systems for mitigating space junk ${ }^{15}$, Earth Observation ${ }^{16}$ and climate change. ${ }^{17}$

\subsection{The Role of Artificial Intelligence in Developing Future Lunar Societies}

The project consisting of building a permanent base on the surface of the Moon, a "Moon village", is considered as being a similarly ambitious undertaking to succeed the International Space Station. ${ }^{18}$

\footnotetext{
${ }^{8}$ Cf. Jet Propulsion Laborator, Strategic Technologies / Science and Technology 11 (2019).

${ }^{9}$ Cf. id.

10 See Ahmed Khairy Noor, Structures Technology for Future Aerospace Systems 11 (AIAA
}

2000).

11 See Walt Truszkowski et Al., Autonomous and Autonomic SYSTEMS: With Applications to NASA INTELLIGENT SPACECRAFT OPERATIONS AND EXPLORATION SYSTEMS 5 (Springer Nov. 2009).

12 See Frank, supra note 1 , at 2.

${ }^{13}$ European Space Agency, "Robots in Space," accessed February 12, 2021,

https://www.esa.int/Enabling_Support/Preparing_for_the_Future/Discovery_and_Preparation/Robots_in_space2

${ }^{14}$ European Space Agency, "Robots in Space," accessed February 12, 2021,

https://www.esa.int/Enabling_Support/Preparing_for_the_Future/Discovery_and_Preparation/Robots_in_space2

15 See Tereza Pultarova April 29 \& 2021, Artificial Intelligence is Learning How to Dodge Space Junk

in Orbit, SPACE.COM, https://www.space.com/Al-autonomous-space-debris-avoidance-esa (last visited Nov. 1, 2021); Prajaktha Gurung, How Al Is Helping Space Debris Removal Efforts, ANALYTICS INDIA MAGAZINE (Jul. 31, 2021), https://analyticsindiamag.com/how-ai-is-helping-space-debris-removalefforts/.

${ }^{16}$ Earth Observation with Artificial Intelligence, INTERREG EUROPE,

https://www.interregeurope.eu/regions4food/news/news-article/9943/earth-observation-with-artificialintelligence/ (last visited Nov. 1, 2021).

17 Harnessing artificial intelligence for climate science, BUREAU DU CLIMAT DE L'ESA, https://climate.esa.int/fr/actualit\%C3\%A9s-et-des-\%C3\%A9v\%C3\%A9nements/harnessing-artificialintelligence-climate-science/ (last visited Nov. 1, 2021).

18 See Éloi Petros, Legal Issues of a Moon Village, 59 InTERnational InStITUTE OF SPACE LAW 37, 37 (2016). 
Establishing the Moon village would involve an inhabited base on the surface of the Moon, thus being the first permanent human presence on another celestial body, ${ }^{19}$ laying the foundations for future Lunar societies.

Al systems will play a double role in the context of future Lunar societies: an ex-ante preparation role and a societal consolidative role. The ex-ante preparation role is mainly connected with Moon exploration missions and the ongoing preoccupations of relevant stakeholders, such as NASA, to enforce autonomous operation procedures. ${ }^{20}$ Historically, NASA's missions have been focused to the Earth-Moon system. Close proximity to Earth allowed instantaneous communications between NASA's Mission Control Center (MCC) and astronauts who rely on the Earth-based MCC for a variety of tasks from technical assistance to daily schedule updates. ${ }^{21}$ In case of equipment malfunctions, MCC is notified by the data being streamed to the ground and MCC uses this information for solving the problem and for sending instructions to the crew. ${ }^{22}$

In the context of increased Lunar activities, these operational procedures no longer seem sustainable. For productivity reasons, astronauts will need to be operationally independent from MCC. Future crews will have to be able to independently monitor vehicle health and to intervene in case of malfunctions, which will only be possible with the help of $\mathrm{Al}$ systems. ${ }^{23} \mathrm{~A}$ high degree of crew autonomy enabled with the help of technology and, in particular, with the help of Al systems, it is considered to represent an important change for mission operations efficiency. ${ }^{24}$

Moon exploration is also closely connected to the deployment of the Lunar rovers..$^{25}$ These autonomous rovers will be especially designed for crew transportation on the Lunar surface and for assisting them during their exploration. Rovers will also be used for exploring the Lunar permanently shadow regions, which are presumably hosting large quantities of water-ice. ${ }^{26}$ In the context of future Lunar societies, naturally occurring water will be an essential resource, therefore shadowed craters and depressions will be a key destination. ${ }^{27}$ For exploring these regions, specifically the South Pole of the Moon, NASA will launch in 2023, the autonomous VIPER rover, which will be in charge with taking pictures of their topography and geology, thus enabling mission preparations. ${ }^{28}$

Capturing images within permanently shadowed regions is exceptionally difficult and, for mitigating such problem, a team of researchers has recently proven the benefits of using a machine learning algorithm, a subset of $\mathrm{Al}$, that helps obtaining a better quality of the pictures ${ }^{29}$ Identifying, mapping and creating databases of the location of Lunar craters is also enabled by the deployment of Al systems. ${ }^{30}$

\footnotetext{
19 See id. at 39.

20 Karl Hille, Text, Automated Technology Allows Unparalleled Space Exploration, NASA, http://www.nasa.gov/feature/goddard/2020/automated-technology-allows-unparalleled-spaceexploration-from-moon-to-asteroids-and-beyond (last visited Nov. 5, 2021).

${ }^{21}$ See Jeremy D. Frank et al., Developing Decision Aids to Enable Human Spaceflight Autonomy, 37

AIMAG No. 4, 46, 46 (2016).

22 See id.

${ }^{23}$ See Paul Ward, The OXford Handbook of EXPertise 844 (Oxford University Press Oct. 2019).

${ }^{24}$ See Frank et al., supra note 21, at 47.

25 See Kathleen Coderre et al., Concept of Operations for the Gateway, in SPACE OPERATIONS: INSPIRING HUMANKIND'S FUTURE 63, 63 (Helene Pasquier et al. eds., Springer International Publishing 2019).

${ }^{26}$ Cf. v. T. Bickel et al., Peering into Lunar Permanently Shadowed Regions with Deep Learning, 12

NatURe Communications No. 1, 5607, 1 (Nature Publishing Group Sep. 2021).

${ }_{27}$ See Thomas A. Mutch, Geology of the Moon: A Stratigraphic View 11 (Princeton University

Press Mar. 2015).

${ }^{28}$ Rick Chen, Text, VIPER, NASA, http://www.nasa.gov/viper (last visited Nov. 5, 2021).

${ }^{29}$ Max Planck Society, Artificial Intelligence Provides Sharper Images of Lunar Craters that Contain Water Ice, https://phys.org/news/2021-09-artificial-intelligence-sharper-images-lunar.html (last visited Oct. 26, 2021).

30 See Chen Yang et al., Lunar Impact Crater Identification and Age Estimation with Chang'E Data by

Deep and Transfer Learning, 11 NATURE COMmUNICATIONS No. 1, 6358, 2 (Nature Publishing Group
} 
Following the exploratory phase, Al systems will contribute for consolidation, playing an assistive role, part of the Lunar societies. Al systems will be able to offer support in daily activities, including offering mental health assistance. Similar systems have already been successfully deployed on the International Space Station (ISS). For example, the Crew Interactive Mobile Companion (CIMON) is the world's first free-flying Al astronaut assistant, developed by IBM and deployed on the ISS. ${ }^{31} \mathrm{CIMON}$ offers support with scientific experiments and its updated version, CIMON-2, contains a feature allowing it to analyse emotion in language and to show empathy when interacting with the astronauts. ${ }^{32}$ Part of its experimental phase, CIMON-2 aims to investigate whether intelligent assistants could help reduce stress during long-term missions. ${ }^{33}$ Previous research already revealed that for diminishing human workload, costs, fatigue driven error and risk in space related activities, human-robot collaboration needs to play an important part. ${ }^{34}$

If proved successful, CIMON and similar Al-based technologies would represent an important assistive technology for future Lunar societies, contributing to the consolidative phase. Space robotics and especially autonomous systems will play a significant role in space exploration and future human societies, by mitigating the harsh environment of the outer space as well by extending existing capabilities with the support of operational autonomy. ${ }^{35}$

\section{Applicable Legal Framework for Potential Damage caused by Artificial Intelligence in a Lunar Context}

From a legal perspective, the establishment of a permanent human base on the surface of the Moon and, in the future, permanent societies, raises a great number of issues from exploration of natural resources, colonization to space tourism. Among potential legal challenges, the matter concerning liability for damage is of crucial importance. In such context, the existing legal framework, more precisely the Outer Space Treaty ${ }^{36}$ and the Liability Convention ${ }^{37}$, should be investigated for identifying any scenarios potentially leading to liability gaps, i.e. situations in which damage occurs but liability cannot be attributed. ${ }^{38}$

\subsection{The Particularities of Liability in International Space Law}

The signing of the Liability Convention marked the culmination of a decade of debate and negotiation of the problem of liability for damage arising from outer space activities. ${ }^{39}$ The negotiations during the drafting phase of the Liability Convention raised a lot of political, economic and social problems. Establishing an appropriate system of legal rules despite the variety of interests involved required a

Dec. 2020); Bob Yirka et al., Using Al to Count and Map Craters on the Moon, https://phys.org/news/2020-12-ai-craters-moon.html (last visited Oct. 26, 2021).

${ }^{31} \mathrm{CIMON}$ Al in Space, IBM, https://www.ibm.com/thought-leadership/innovation-explanations/cimonai-in-space (last visited Nov. 3, 2021).

32 Mike Wall December 05 \& 2019, New, Emotionally Intelligent Robot CIMON 2 Heads to Space Station, SPACE.COM, https://www.space.com/cimon-2-artificial-intelligence-robot-space-station.html (last visited Nov. 7, 2021).

${ }^{33}$ CIMON Al in Space, supra note 31, at 2.

${ }^{34}$ See Scott A. Green et al., Human-Robot Collaboration: A Literature Review and Augmented Reality Approach in Design, 5 INTERNATIONAL JOURNAL OF AdVANCED RoBOtIC SYSTEMS 1, 1 (SAGE Publications Mar. 2008).

${ }^{35}$ Cf. University of Sheffield et al., Space Robotics \& Autonomous Systems: Widening the Horizon of Space Exploration 7 (UK-RAS Network 1st ed. Jun. 2018).

${ }^{36}$ Treaty on Principles Governing the Activities of States in the Exploration and Use of Outer Space, Including the Moon and Other Celestial Bodies, of 27 January 1967, entered into force on 10 October 1967; text in 610 UNTS 205, 18 UST 2410 [hereinafter the Outer Space Treaty]

${ }^{37}$ Convention on International Liability for Damage Caused by Space Objects, of 29 March 1972, entered into force on 1 September 1972 [hereinafter the Liability Convention]

${ }^{38} \mathrm{Cf}$. Bratu et al., supra note 5, at 423.

39 W. F. Foster, The Convention on International Liability for Damage Caused by Space Objects, 10

CANADIAN YEARBOOK OF INTERNATIONAL LAW 137, 143 (1972). 
new approach, differing from traditional concepts of liability for damage elaborated in domestic systems of law of particular States, as well as in international law. ${ }^{40}$ This new approach had to balance the interests of the states with the legitimate interests of victims of space activities. ${ }^{41}$ Despite all the challenges posed during the drafting process, the resulting Liability Convention managed to address complex matters relating to space activities. At the same time, it provides relatively clear guidelines for a determination as to who may be liable, the scope of damage falling within the terms of the Convention, who may bring claims for compensation, how those claims may be brought and by what method the appropriate compensation is to be calculated. ${ }^{42}$

The Liability Convention provides a unique setting in international law in what concerns liability regimes, by mentioning both absolute and fault-based liability. Moreover, even though it does not specifically mention this, the Liability Convention is not the sole mechanism for obtaining reparations in case of a damage caused by a space object. Invoking Article VI of the Outer Space Treaty referring to international responsibility remains a theoretical yet viable option for such reparation. Nevertheless, the present paper will focus on Article VII of the Outer Space Treaty, as detailed by the provisions of the Liability Convention and will not analyse Article VI of the Outer Space Treaty and the corresponding doctrinal debates on whether this article represents a back-up option for obtaining reparations. ${ }^{43}$

As such, Article VII of the Outer Space Treaty provides that a state which launches or procures the launching of an object into outer space or from whose territory or facility an object is launched, is internationally liable for damage to another state party to the Outer Space Treaty. ${ }^{44}$ Building on these provisions, the Liability Convention offers a comprehensive framework by which liability for damage caused by space objects is assigned to states. ${ }^{45}$ The Liability Convention formally labelled such states as "launching states" and further elaborated the liability regime actually applied to such damage ${ }^{46} \mathrm{~A}$ "launching state" is a "state which launches or procures the launching of a space object," or a "state from whose territory or facility a space object is launched." 47

In determining the standard of liability, the Liability Convention distinguishes between the two locations where damage may occur. In relation to damage caused on the surface of the Earth or to aircraft in

\footnotetext{
40 Jerzy Rajaki, Convention on International Liability for Damage Caused by Space Objects - An Important Step in the Development of the International Space Law Part IV - Various Subjects, 17 PROC. ON L. OUter SPACE 245, 245 (1974).

41 ld.

${ }^{42}$ Steven Freeland, There's a Satellite in My Backyard - Mir and the Convention on International Liability for Damage Caused by Space Objects, 24 U.N.S.W.L.J. 462, 470-73 (2001).

${ }^{43}$ For a detailed discussion on the topic, please refer to Frans von der Dunk, Liability versus Responsibility in Space Law: Misconception or Misconstruction?, PROCEEDINGS OF THE THIRTY-FOURTH COLLOQUIUM ON THE LAW OF OUTER SPACE 363 (1991).

${ }^{44}$ Paul B. Larsen, Liability Limitation under National Law and the Liability Convention 53rd Colloquium on the Law of Outer Space: 5. Recent Developments in Space Law, 53 PROC. INT'L INST. SPACE L. 416, 419 (2010).

${ }^{45}$ Dempsey P.S., National Laws Governing Commercial Space Activities: Legislation, Regulation, \& Enforcement, 36 NORTHWESTERN JOURNAL OF INTERNATIONAL LAW AND BUSINESS 1, 9 (2016); Simona Spassova \& Andreas Loukakis, The Legal Implications of Erroneous GNSS Signal, Resulting from Harmful Interference 58th IISL Colloquium on the Law of Outer Space - Jerusalem, Israel: 1st Session, 58 PROC. INT'L INST. SPACE L. 79, 88 (2015); Andre G. Debusschere, Liability for Damage Caused by Space Objects, 3 J. INT'L L. \& PRAC. 97, 101 (1994).

46 FRANS VON DER DUNK \& FABIO TRONCHETTI, HANDBOOK OF SPACE LAW 82 (Edward Elgar Publishing 2015); VALÉRIE KAYSER, LAUNCHING SPACE OBJECTS: ISSUES OF LIABILITY AND FUTURE PROSPECTS 34 (Kluwer Academic Publishers 2001); Frans von der Dunk, The 1972 Liability Convention: Enhancing Adherence and Effective Application, PROCEEDINGS OF THE FORTY-FIRST COLLOQUIUM ON THE LAW OF OUTER SPACE 366, 367 (1998); OUTER SPACE IN SOCIETY, POLITICS AND LAW 340-41 (Christian Brünner \& Alexander Soucek eds., Springer-Verlag 2011); FABIO TrONCHETTI, FUNDAMENTALS OF SPACE LAW AND POLICY 10-11 (Springer 2013); CARL Q. CHRISTOL, THE MODERN INTERNATIONAL LAW OF OUTER SPACE 62-65 (Pergamon Press 1982).

47 Article I c), Liability Convention
} 
flight, the Liability Convention establishes an absolute liability system, irrespective of fault. For situations of damage occurred in other places rather than the surface on Earth or to aircraft in flight, the Liability Convention stipulates for a fault-based liability system. ${ }^{48}$ The two different systems of liability were also interpreted in the legal doctrine as a risk categorisation. For example, Rajaky argues that the formulation on the basis of liability for "space damages" in the Liability Convention has been differentiated according to the risks involved by space activities and to the character of damage caused. The Liability Convention took in consideration the different environments and circumstances in which the damage may be caused. 49

The incorporation in the Liability Convention of the concept of absolute liability for damage represents a novelty for international law..$^{50}$ Usually, it is required that a certain standard of fault applies before the liability of a state can be sought. ${ }^{51}$ The reason behind the introduction of absolute liability is the fact that space activities are generally considered dangerous ${ }^{52}$, meaning that they create an extraordinary risk to persons and properties. ${ }^{53}$ In the face of the hazardous environment of outer space, an absolute liability regime ensures compensation and a requirement of fault would weaken an effective victimoriented compensation mechanism. ${ }^{54}$

In what concerns the fault-based liability system, the reasons behind the integration of such a mechanism in Article III of the Liability Convention was that, in space, all parties in the position to operate a space object are equal and they have access to relevant data and technology allowing them to bring proof of fault. ${ }^{55}$ In any case, it should be considered that they have assumed the risks of conducting these activities, therefore, none of the participants in space activities should be a privileged victim. ${ }^{56}$ Even if launching states have access to necessary data, which, in theory, may offer grounds for proving fault in case of a damage caused by their space object, this does not automatically mean that proving fault is always a straightforward process.

\subsection{Quo Vadis Moon Liability: Challenges posed by Artificial Intelligence in a Lunar Context}

According to Article 14 (2) of the Moon Agreement57, the State Parties acknowledge that detailed arrangements concerning liability for damage caused on the Moon, in addition to the provisions included in the Outer Space Treaty and in the Liability Convention, "may become necessary as a result of more extensive activities on the Moon". Consequently, in the absence of any such "detailed arrangements", the provisions of the Outer Space Treaty and of the Liability Convention remain applicable for any damage caused by a space object in a Lunar context. More precisely, taking in consideration the geographical criterium imposed by the Liability Convention ${ }^{58}$, any damage caused by a space object of one state to a space object of another state will be compensated subject to proof of fault, in accordance with Article III of the Liability Convention.

48 Spassova \& Loukakis, supra note 45, at 89; Rod Margo, Some Aspects of Insuring Satellites, 1979 INS. L.J. 555, 561 (1979).

49 Rajaki, supra note 40 , at 250.

50 MaLCOLM SHAW, INTERNATIONAL LAW 545 (Cambridge University Press 6th ed. 2008). 51 ld.

${ }^{52}$ R. Venkata Rao et al., Recent Developments in Space Law : Opportunities \& Challenges 86 (Springer Verlag),

https://search.ebscohost.com/login.aspx?direct=true\&scope=site\&db=nlebk\&db=nlabk\&AN=1616446.

53 KAYSER, supra note 46 , at 51.

54 DUNK \& TRONCHETTI, supra note 46, at 586; MARIETTA BENKÖ ET AL., SPACE LAW: CURRENT

PROBLEMS AND PERSPECTIVES FOR FUtURE REGULATION 92-111 (Eleven International 2005).

${ }^{55}$ Foster, supra note 39 , at 154.

56 KAYSER, supra note 46 , at 51.

${ }^{57}$ Agreement Governing the Activities of States on the Moon and Other Celestial Bodies, 18

December 1979, UN resolution 34/68 of 5 December 1979, annex; 18 I.L.M. 1434 (entered into force: 11 July 1984) [hereinafter the Moon Agreement].

58 Please refer to Section 3.1 above 
The increasing number of activities on the surface of the Moon, including the envisaged establishment of Lunar societies led to doctrinal debates on whether a fault-based liability system would offer adequate solutions to the possible incidents which might place on the surface of the Moon. For example, the faultbased liability system would be applicable even when an expensive station placed on the Moon would be damaged by identifiable debris. ${ }^{59}$ In theory, this would cause a severe economic impact for the State owing the station and, potentially, would lead to hindering the development of human settlements on the surface of the Moon.

As emphasized above, the reasons behind imposing an absolute liability for damage originated as a measure of victims' protection against possible hazardous activities. ${ }^{60}$ Based on this rationale, in the legal doctrine, it was mentioned that the extreme conditions on the surface of the Moon would equally qualify as possible hazardous activities requiring an absolute liability regime. ${ }^{61}$

The advent of Al in the context of space related activities further challenges the existing liability systems established by the Liability Convention. ${ }^{62}$ Such challenges especially revolve around the Moon-fault based liability system, especially because the notion of "fault" is not defined in international space law. ${ }^{63}$ In the absence of such a definition and of interpretation rules included in the any of the space treaties, it is required to apply the fall-back mechanisms, meaning to make use of the general international law. Vienna Convention on the Law of Treaties, the final and authoritative achievement on treaty interpretation ${ }^{64}$, provides that, among others, "a treaty shall be interpreted in good faith in accordance with the ordinary meaning to be given to the terms of the treaty $(\ldots)$ ". ${ }^{65}$ Pursuant to the Cambridge Dictionary, "fault" is defined as "a mistake, especially something for which you are to blame" 66 . Black's Law Dictionary defines fault as "an error or defect of judgement or of conduct; any deviation from prudence or duty resulting from inattention (...); the intentional or negligent failure to maintain some standard of conduct when the failure results in harm to another person". ${ }^{67}$ The analysis of these two definitions reveals that "fault liability" can be defined as implying a type of liability in which the plaintiff must prove that the defendant's conduct was either negligent or intentional. ${ }^{68}$ However, producing such proof might be difficult in the context of advanced Al systems, learning and operating on their own. Moreover, in the context of Article III of the Liability Convention, the expression "fault of the persons" also requires special attention. Given the absence or reduced human control involved in the operation

59 See Gennady Zhukov, Problem of Absolute Liability on the Moon, The 52nd Colloquium on the Law of Outer Space: 3. Third Party Liability Issues in Commercial Space Activities, 52 Proc. INT'L INST. SPACE L. 251, 251 (2009).

60 Please refer to Section 3.1 above

61 See Zhukov, supra note 59, at 253.

62 See Anne-Sophie Martin \& Steven Freeland, The Advent of Artificial Intelligence in Space Activities: New Legal Challenges, 55 SPACE POLICY 101408, 6 (Feb. 2021).

$63 \mathrm{Cf}$. Bratu et al., supra note 5, at 433.

64 Ulf Linderfalk, Is the Hierarchical Structure of Article 31 and 32 of the Vienna Convention Real or Not? Interpreting the Rules of Interpretation, 54 NETHERLANDS INTERNATIONAL LAW REVIEW 133, 433 (2007); E. Criddle, The Vienna Convention on the Law of Treaties in U.S. Treaty Interpretation, 44 VIRGINIA JOURNAL OF INTERNATIONAL LAW 431, 431-33 (2004); See also the following ICJ decisions recognising Vienna Convention as the authoritative document in treaty interpretation: Guinea-Bissau v. Sen., Oops. Novel citation pattern. (Jul. 31, 1989), https://www.icj-cij.org/en/case/82;

Kasikili/Sedudu Island (Bots. v. Namib.), Oops. Novel citation pattern. (International Court of Justice Dec. 13, 1999), https://www.icj-cij.org/en/case/98.

${ }^{65}$ Art. 31 Vienna Convention on the Law of Treaties (adopted 23 May 1969, entered into force 27 January 1980) 1155 UNTS 331, 8 ILM 679

${ }^{66}$ Fault, CAMBRIDGE DICTIONARY, https://dictionary.cambridge.org/dictionary/english/fault (last visited Oct. 31, 2021).

${ }^{67}$ Frans von der Dunk, Too-Close Encounters of the Third Party Kind: Will the Liability Convention Stand the Test of the Cosmos 2251-Iridium 33 Collision?, SPACE, CYBER, AND Telecommunications LaW PROGRAM FACULTY PUBLICATIONS (Jan. 2010), https://digitalcommons.unl.edu/spacelaw/28. 68 Ibid. 
of Al systems, it may be argued that a potential damage is no longer caused due to a "fault of a person", leading to difficulties in attributing liability. ${ }^{69}$

The legal doctrine has already started to envisage various potential scenarios in which Al systems malfunction, thus identifying the difficulties of attributing liability. In a recent paper, Professor Freeland emphasizes the following risks posed by the introduction of Al systems in space related activities: "If something goes wrong with a fully autonomous satellite, for example, the question arises as to who is the party responsible, and liable, in the case of damage involving personal injury or property, or a failure to comply with national and/or international rules and regulations. Significant (potential) liability may arise in the event of a satellite failure, collision, destruction or cyber-security incident, and the legal position as to how to resolve any claims e and indeed, against whom the claims should be made e will require clarification". ${ }^{70}$

\section{Recommendations: Proposal for an Action Plan on Moon Liability}

Anticipating and further proposing mitigating actions for dealing with legal challenges imposed by advanced technologies, such as Al systems, becomes of stringent importance in the context of future Lunar societies. Two alternative options may be considered, as follows:

i. initiating the review and the amendment of the Moon Agreement.

The developments Al systems, together with ample resources in outer space, make space activities becoming more complex than at the time when the Moon Agreement was drafted. Even the signatories of the Agreement acknowledged in Article 18 the necessity of its review "taking into account in particular any relevant technological developments". Nevertheless, such process may prove laborious and lengthy. Previous experiences, such as the negotiation of the Liability Convention, showed that conflicting interests, both politic and economic, may hinder reaching consensus. Notwithstanding this, envisaging future Lunar societies in the context of recent technological advancement might prove difficult to be implemented in the existing regulatory framework.

ii. embracing the "rules of the road approach" by establishing transparency and confidence building measures related to $\mathrm{Al}$ in space activities. ${ }^{71}$

Such measures refer to instruments intended to create a more positive cooperative environment for the carrying out of outer space activities may include from encouraging responsible behaviour, international consultations, informing the public about space activities, to providing alerts concerning potential dangers to astronauts. ${ }^{72}$ Even though they are not legally binding, over the years, the international community has been using "best practices" or "rules of conduct" for encouraging collaboration and sustainable space activities. ${ }^{73}$

\section{Conclusions}

Al systems have a beneficial role in advancing space exploration and supporting astronauts with their tasks. In the context of future Lunar societies, these systems will play an important part, both in an investigative ex-ante phase as well in the process of further development and consolidation of these permanent human habitats.

The integration of Al systems in space related activities does not come without legal consequences. The "Moon liability" problem is one of the most important, especially in the context of the lacunar provisions of international space law, such as the Outer Space Treaty, the Liability Convention and the Moon Agreement. For avoiding potential liability gaps, immediate actions are required, either at a

69 See Bratu et al., supra note 5, at 437.

${ }^{70}$ Martin \& Freeland, supra note 62.

${ }^{71}$ Cf. id. at 7.

72 Cf. id.

${ }^{73}$ Cf. id. 
regulatory level (such as the review and the amendment of the Moon Agreement) or by initiating best practices for the use of $\mathrm{Al}$ in a Lunar context. 


\section{BIBLIOGRAPHY}

Guinea-Bissau v. Sen., Oops. Novel citation pattern. (International Court of Justice Jul. 31, 1989), https://www.icj-cij.org/en/case/82.

Kasikili/Sedudu Island (Bots. v. Namib.), Oops. Novel citation pattern. (International Court of Justice Dec. 13, 1999), https://www.icj-cij.org/en/case/98.

Marietta Benkö et al., Space law: Current Problems and Perspectives for Future Regulation (Eleven International 2005).

v. T. Bickel et al., Peering into Lunar Permanently Shadowed Regions with Deep Learning, 12 Nature Communications No. 1, 5607 (Nature Publishing Group Sep. 2021).

Ioana Bratu et al., Autonomous Space Objects and International Space Law: Navigating the Liability Gap, 18 INDONESIAN JOURNAL OF INTERNATIONAL LAW 423 (Mar. 2021).

Bertrand Braunschweig \& Malik GHallab, Reflections on ARTificial INTELLIGENCE FOR Humanity (Springer 2021).

Carl Q. Christol, The Modern International Law of Outer Space (Pergamon Press 1982).

E. Criddle, The Vienna Convention on the Law of Treaties in U.S. Treaty Interpretation, 44 VIRGINIA JOURNAL OF INTERNATIONAL LAW 431 (2004).

Andre G. Debusschere, Liability for Damage Caused by Space Objects, 3 J. INT'L L. \& PRAC. 97 (1994).

Dempsey P.S., National Laws Governing Commercial Space Activities: Legislation, Regulation, \& Enforcement, 36 NORTHWESTERN JOURNAL OF INTERNATIONAL LAW AND BUSINESS 1 (2016).

Frans von der Dunk, Liability versus Responsibility in Space Law: Misconception or Misconstruction?, PROCEEDINGS OF THE THIRTY-FOURTH COLLOQUIUM ON THE LAW OF OUTER SPACE 363 (1991).

Frans von der Dunk, The 1972 Liability Convention: Enhancing Adherence and Effective Application, PROCEEDINGS OF THE FoRTY-FIRST COLLOQUIUM ON THE LAW OF OUTER SPACE 366 (1998).

Frans von der Dunk, Too-Close Encounters of the Third Party Kind: Will the Liability Convention Stand the Test of the Cosmos 2251-Iridium 33 Collision?, SPACE, CYBER, AND TELECOMMUNICATIONS LAW PROGRAM FACULTY PUBLICATIONS (Jan. 2010), https://digitalcommons.unl.edu/spacelaw/28.

Frans von der Dunk \& FABio Tronchetti, HandBook of Space LaW (Edward Elgar Publishing 2015).

W. F. Foster, The Convention on International Liability for Damage Caused by Space Objects, 10 CANADIAN YEARBOOK OF INTERNATIONAL LAW 137 (1972).

Jeremy D. Frank et al., Developing Decision Aids to Enable Human Spaceflight Autonomy, 37 AIMAG No. 4, 46 (2016).

Jeremy D. Frank, Artificial Intelligence: Powering Human Exploration of the Moon and Mars, ARXIV:1910.03014 [CS] (Oct. 2019).

Steven Freeland, There's a Satellite in My Backyard - Mir and the Convention on International Liability for Damage Caused by Space Objects, 24 U.N.S.W.L.J. 462 (2001).

Scott A. Green et al., Human-Robot Collaboration: A Literature Review and Augmented Reality Approach in Design, 5 INTERNATIONAL JOURNAL OF ADVANCED ROBOTIC SYSTEMS 1 (SAGE Publications Mar. 2008). 


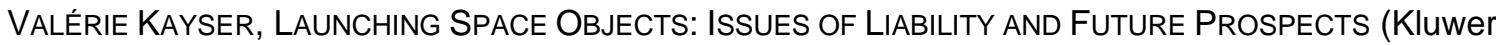
Academic Publishers 2001).

Paul B. Larsen, Liability Limitation under National Law and the Liability Convention 53rd Colloquium on the Law of Outer Space: 5. Recent Developments in Space Law, 53 PROC. INT'L INST. SPACE L. 416 (2010).

Ulf Linderfalk, Is the Hierarchical Structure of Article 31 and 32 of the Vienna Convention Real or Not? Interpreting the Rules of Interpretation, 54 NETHERLANDS INTERNATIONAL LAW REVIEW 133 (2007).

Rod Margo, Some Aspects of Insuring Satellites, 1979 INS. L.J. 555 (1979).

Anne-Sophie Martin \& Steven Freeland, The Advent of Artificial Intelligence in Space Activities: New Legal Challenges, 55 SPACE POLICY 101408 (Feb. 2021).

Thomas A. Mutch, Geology of the Moon: A Stratigraphic View (Princeton University Press Mar. 2015).

Ahmed Khairy NoOR, Structures TeChnology for Future Aerospace Systems (AIAA 2000).

Éloi Petros, Legal Issues of a Moon Village, 59 INTERnAtIONAL INSTITUTE OF SPACE LAW 37 (2016).

Jerzy Rajaki, Convention on International Liability for Damage Caused by Space Objects - An Important Step in the Development of the International Space Law Part IV - Various Subjects, 17 PROC. ON L. OUTER SPACE 245 (1974).

MALCOLm SHAW, INTERnAtional LAW (Cambridge University Press 6th ed. 2008).

Simona Spassova \& Andreas Loukakis, The Legal Implications of Erroneous GNSS Signal, Resulting from Harmful Interference 58th IISL Colloquium on the Law of Outer Space - Jerusalem, Israel: 1st Session, 58 PROC. INT'L INST. SPACE L. 79 (2015).

Fabio Tronchetti, Fundamentals of Space Law ANd Policy (Springer 2013).

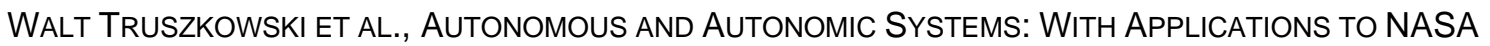
INTELLIGENT SPACECRAFT OPERATIONS AND EXPLORATION SYSTEMS (Springer Nov. 2009).

Paul Ward, The OXford Handbook of Expertise (Oxford University Press Oct. 2019).

Chen Yang et al., Lunar Impact Crater Identification and Age Estimation with Chang'E Data by Deep and Transfer Learning, 11 NATURE COMMUNICATIONS No. 1, 6358 (Nature Publishing Group Dec. 2020).

Gennady Zhukov, Problem of Absolute Liability on the Moon, The 52nd Colloquium on the Law of Outer Space: 3. Third Party Liability Issues in Commercial Space Activities, 52 Proc. INT'L INST. SPACE L. 251 (2009).

OUTER SPACE IN SOCIETY, POLITICS AND LAW (Christian Brünner \& Alexander Soucek eds., SpringerVerlag 2011).

Tereza Pultarova April 29 \& 2021, Artificial Intelligence is Learning How to Dodge Space Junk in Orbit, SPACE.COM, https://www.space.com/Al-autonomous-space-debris-avoidance-esa (last visited Nov. 1, 2021).

Rick Chen, Text, VIPER, NASA, http://www.nasa.gov/viper (last visited Nov. 5, 2021). 
Kathleen Coderre et al., Concept of Operations for the Gateway, in SPACE OPERATIONS: INSPIRING HUMANKIND'S FUTURE 63 (Helene Pasquier et al. eds., Springer International Publishing 2019).

Mike Wall December 05 \& 2019, New, Emotionally Intelligent Robot CIMON 2 Heads to Space Station, SPACE.COM, https://www.space.com/cimon-2-artificial-intelligence-robot-space-station.html (last visited Nov. 7, 2021).

European Parliament and Council, Draft Report with Recommendations to the Commission on a Civil Liability Regime for Artificial Intelligence, No. P9_TA(2020)0276 (Apr. 2020).

Prajaktha Gurung, How Al Is Helping Space Debris Removal Efforts, ANALYTICs INDIA MAGAZINE (Jul. 31, 2021), https://analyticsindiamag.com/how-ai-is-helping-space-debris-removal-efforts/.

Karl Hille, Text, Automated Technology Allows Unparalleled Space Exploration, NASA, http://www.nasa.gov/feature/goddard/2020/automated-technology-allows-unparalleled-spaceexploration-from-moon-to-asteroids-and-beyond (last visited Nov. 5, 2021).

Jet Propulsion Laborator, Strategic Technologies / Science and Technology (2019).

Max Planck Society, Artificial Intelligence Provides Sharper Images of Lunar Craters that Contain Water Ice, https://phys.org/news/2021-09-artificial-intelligence-sharper-images-lunar.html (last visited Oct. 26, 2021).

University of Sheffield et al., Space Robotics \& Autonomous Systems: Widening the Horizon of Space Exploration (UK-RAS Network 1st ed. Jun. 2018).

R. Venkata Rao et al., Recent Developments in Space Law : Opportunities \& Challenges (Springer Verlag), https://search.ebscohost.com/login.aspx?direct=true\&scope=site\&db=nlebk\&db=nlabk\&AN=1616446.

Bob Yirka et al., Using Al to Count and Map Craters on the Moon, https://phys.org/news/2020-12-aicraters-moon.html (last visited Oct. 26, 2021).

What is Artificial Intelligence and How is It Used? / News / European Parliament, https://www.europarl.europa.eu/news/en/headlines/society/20200827STO85804/what-is-artificialintelligence-and-how-is-it-used (last visited Feb. 14, 2021).

CIMON Al in Space, IBM, https://www.ibm.com/thought-leadership/innovation-explanations/cimon-aiin-space (last visited Nov. 3, 2021).

Earth Observation with Artificial Intelligence, INTERREG EUROPE, https://www.interregeurope.eu/regions4food/news/news-article/9943/earth-observation-with-artificialintelligence/ (last visited Nov. 1, 2021).

Harnessing artificial intelligence for climate science, BUREAU DU CLIMAT DE L'ESA, https://climate.esa.int/fr/actualit\%C3\%A9s-et-des-\%C3\%A9v\%C3\%A9nements/harnessing-artificialintelligence-climate-science/ (last visited Nov. 1, 2021).

Fault, CAMBRIDGE DICTIONARY, https://dictionary.cambridge.org/dictionary/english/fault (last visited Oct. 31, 2021). 